\title{
Communication of Performing Art "Tanah" of Theatre CCL Bandung as Sociocultural Construction
}

\author{
Jaeni and Afri Wita \\ Theatre Department of ISBI Bandung, Jln. Buahbatu No 212 Bandung, Indonesia
}

The research is financed by Directorate of Research and Public Service of the Ministry of Research, Technology, and Higher Education of Republic of Indonesia

\begin{abstract}
Contemporary theatre performing art is media of art communication deriving from the ideas of the artists to express phenomena existing in their sociocultural surroundings. This study is aimed at analizing and interpreting the expression of theatre performance which can be answers, expectation, criticism, and picture of the past, the present and the future life. The expression is communicated through the art of theatre either dramatically, kinesthetically, musicalistically, or visualistically by the performers who all at once construct their society related to the socioculture life experienced in their surrounding. The method applied in this research is qualitative approach with interpretative spirit in phenomenology perspective. This method focuses on in-depth interview, participant observation, and self reflection through the experience of experiment work on Indonesian contemporary theatre performance. The result of the study shows that the theatre group of CCL Bandung supporting the problems of "land" offers a distinctive answer and solution which are relatively different from their surroundings and the society in general. Furthermore, the cultural and social information in contemporary theatre performance can be knowledge, understanding, and a particular viewpoint in answering the sociocultural challenge in the present days
\end{abstract}

Keywords: Social Construction, Theatre Performance, Art Communication

\section{Introduction}

Performing art communication is inseparable from the events of performances whose messages are resulted from elements such as drama, dance, music, and fine art or visualization. This communication study of performing art has two components usually conducted in the research of cultural communication. Those two components cover culture and communication (Rakhmat, 2000: 242-245). Considering culture and communication on the form of theatre performing art, this study is focussed on the constructive efforts of communication of contemporary theatre performing art in Indonesia represented by elements of drama, dance, music, and visual.

There is a problem in the performing art nowadays since most of the observers, the cultural elites, the artists, as well as the academics tend to see the performing art merely from the form. Meanwhile the perspective of art communication with its existence as the essence of performance which delivers cultural and social information is neglected.

The characteristic of information or message in the communication of contemporary theatre peforming art is not the same as the communication in social field or cultural commuication. Information and messages in the communication of contemporary theatre performing art can be very complicated, since it is a small world represented symbolically. The complexity of communication messages in the contemporary theatre performing art requires interpretation of the symbolic meanings represented in drama, dance, music, and visual. Moreover, the interpretation of those symbolic meanings is directed into knowledges, understanding, and constructive views on sociocultural phenomena faced by the society nowadays.

There are many performances of Indonesian contemporary theatre which are not easy to be understood by the public. The ideas of the theatre performers actualized in the elements of dramatics, dance, music, and visual/artistics staged in the performance seem free from context and the communication understanding of their publics. On the contrary, when the elements of drama, dance, music, and visual of the Indonesian contemporary theatre performances can be understood, they are merely an entertainment without messages that can be explored. Furthermore, the performances of Indonesian contemporary theatre should actually become a communication event which does not only study the content of the message and the subjects who conduct the communication, but also how the media, codes, and setting of the communication are going on (Burke, 2003: 144-145) to deal with the sociocultural problems of the society surrounding. 
This study refers to the previous research on communication of performing art (Jaeni, 2007) stating that "performing art is a media of symbolic communication". In the context of communication, symbol is something that can be interchangeable either in verbal or non-verbal communication. Lustig and Koster (Liliweri, 2003:13) urges that the cultural life (including performing art) is also a space of symbolic, interpretative, transactional, and contextual communication conducted by some people giving different interpretation and expectation from what is delivered.

Few will argue that the world of performing art is also the world of communication (social) with the touching of arts. Richard Bauman (1992: 44) explains that, "A performance is a communication event conceptualized in the performing art through the conception of specific communication acts also in the specific form and meaning interpration in line with the cultural context surrounding it. Realizing the intimacy between arts and communication, Jaeni (2012: 15) offers a study that should be explored further related to the performing art communication of Indonesian contemporary theatre. This is especially on the form of art communication which is related to symbolic arts through the elements of performance such as drama, dance, music, and fine art, as well as the interaction between the performers and the publics. On the other side, performing art is also a social reality (Jaeni, 2014: 40) whose existence is not free from construction efforts of individuals to answer sociocultural phenomena of the society. This is in line with Berger and luckmann paradigm (1966) about social construction, that is, social reality is an existence and social world structure depending on the individual that becomes the subject.

This study of performing art communication of Indonesian contemporary theatre is conducted based on the problems above by focusing on the phenomena of performance "Tanah (Land)" performed by CCL Theatre Group Bandung, West Java. The meaning and message of art communication of performance "Tanah" is analyzed in the form of dramatic, kinesthetic, musicalistic, and visualistic as constructive efforts in handling sociocultural problems.

\section{Method}

Research on performing art communication is a type of research that can be distinguished, either from the research on communication itself or the research on performing art. This is because the type of performing art communication is indeed different from the usual communication, either from the process or the way in giving messages.

The method applied in this reseach is qualitative approach with interpretative spirit in phenomenology perspective. This method focuses on in-depth interview, participation observation, and sefl reflection toward Indonesian contemporary theatre performance. The informants of this research are some artists and groups of Indonesian contemporary theatre and their publics whose experience become the main resource for this research. A number of documents (especially Theatre CCL's Bandung) become significant data to study performing art communication of Indonesian contemporary theatre todays.

The research method of performing art communication of Indonesian contemporary theatre is conducted as flowchart of the target seen as follows. 


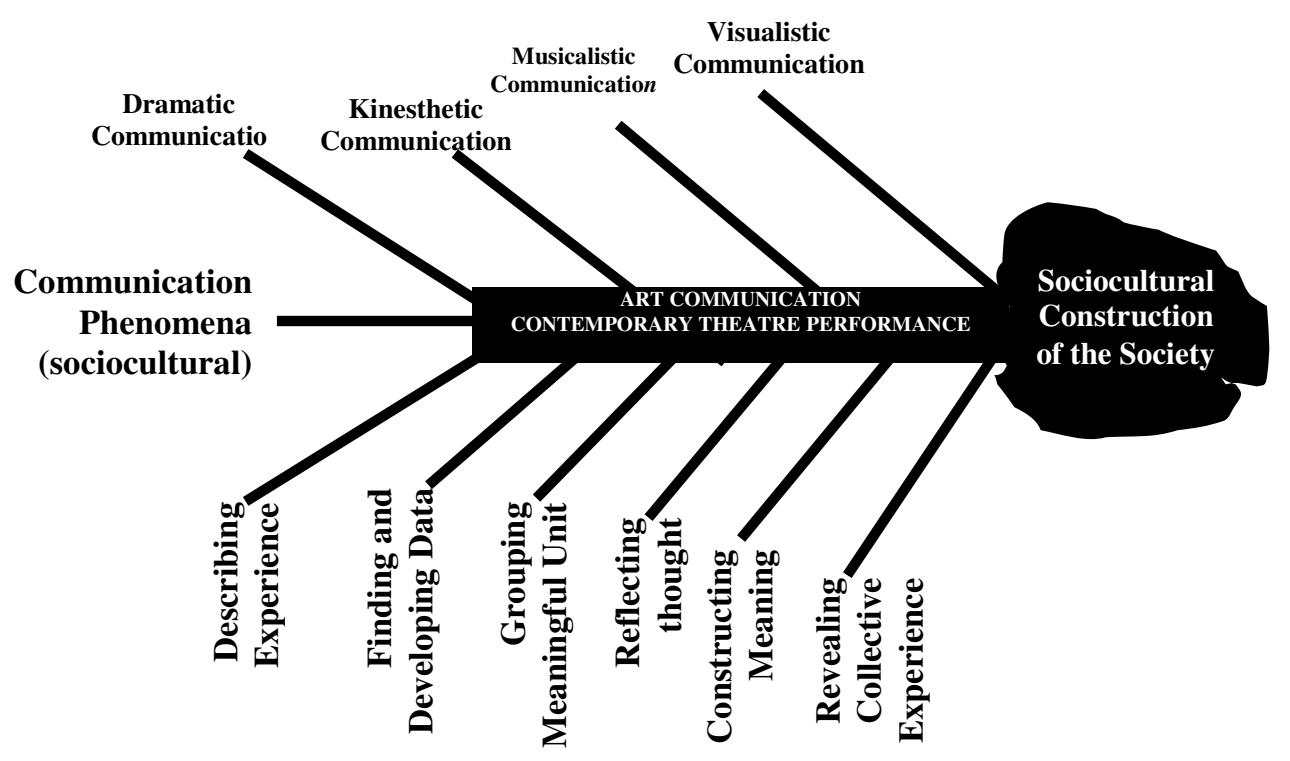

Picture 1. The research method of performing art communication of contemporary theatre

The flowchart above is presented by following communication phenomenology study (Kuswarno, 2009: 137) which represents the research work of the researcher team. There are four forms of communication (dramatic, kinesthetic, musicalistic, and visualistic) in the research of performing art communication of Indonesian contemporary theatre in which the message and the communication process should be studied through the following series of activities.

1. Describing the whole experience of the performer and the public of contemporary theatre

2. Seeking for the statement of data horizonalization on the form of art communication and developing it without doing repetition or overlapping;

3. Grouping the statements in meaning unit from each form and process of performing art communicatio $\mathrm{n}$ of Indonesian contemporary theatre, and giving textural description about the experience including the examples thoroughly;

4. Doing thought reflection and using imaginative variation toward contemporary theatre performance as a part of experience verification. Moreover, the whole message is seeked for through divergent perspectives by considering the references toward the phenomenon, and constructing how the phenomenon is undergone;

5. Constructing the whole explanation about meaning and essence of the experience through performances of Indonesian contemporary theatre to find indicators of sociocultural construction toward knowledge, understanding, and the world view.

6. Revealing the experience of the researchers and participants by writing the composite description

\section{Result and Discussion}

\subsection{Teater Celah-Celah Langit (CCL) Bandung and Performance "Tanah"}

A house should become an inspiration of civilization. A house is not only for a shelter but also a civilization, that is a mixing place of all aspects, a place for playing and gathering, having meal together, a place for water to flow, a library or a learning place full of knowledge, a place where love, affection, and culture are embedded. A house becomes a space of harmony. That is what CCL dreams for a house as a source of civilization.

A theatre group, Celah-celah Langit (CCL), was born from a house in Ledeng, North Bandung, created by Sawung Jabo, the important one from Kantata Takwa music group, in May 21, 1t998. The emergence of the theatre group CCL was concurrent with the falling down of Soeharto as the president of Indonesian Republic. That night became a thanksgiving evening for CCL representing the artists for their freedom from the suppression and control from the government. In that era, the freedom for art was restricted, creative ideas were silenced, and expressions are blinded. Therefore, the thanksgiving for the freedom was expressed through theatre performance, entitled, "Mei" (May).

The house of CCL group is never quiet from dwellers and visitors who are artists, either from theatre, fine art, literature, even journalists. The civilization house is a space to discuss art culture, and is also visited by 
surrounding people from various professions. On the other side, Iman Soleh as the owner of CCL house and also a theare lecturer in an art institute frequently takes his students to explore ideas and creativity, and holds a performance involving people surrounding his house. This culture celebration conducted by CCL is in order not to be isolated from his surrounding. Therefore, the performances held by CCL give more priority to involve the people surrounding his house.

Theatre CCL Bandung through its leader, Iman Soleh, holds a simple principle, that is, devoting to art is self esteem. To actualize the creativity in art cannot be done by begging. "To be devoted to art is self esteem, art is our face and how we present our art, in and by what way, will show who we are" (interview with Iman Soleh, Bandung, May 22, 2015). For this reason, CCL never writes a proposal to propose for a budget. However, they welcome those who intend to supply the budget to actualize their art. In fact, they support any parties, either private or public, to help actualizing art but without intervention and sponsor message, because art is part of the freedom to express.

On the other side, theatre CCL supports the culture spirit to give back the values of local wisdom by conserving the culture of the surroundings. The view of the people should actually have thought about how art is not merely an entertainment but more as dedication to the universe and gratitude to the God for what has been given through the nature. Based on that thought about the universe, the CCL theatre performances are always related to the harmony of the nature, for example, performances, "Tanah" (Land), "Air" (Water)", and "Ozon" (Ozone). Those performances communicate the concern to the nature that has been contaminated, old, broken, and related to the not responsible people for the ecosystem protection.

For example, the performance "Tanah" is a performance trying to reconstruct the public thought about the problems of land. Staging "Tanah" is not free from the research results on the land itself. The land can be seen from legal aspects of a country such as agrarian law in 1970. The land in Indonesia can also be a history reminder such as plantations controlled over by VOC. Besides, the problems of land in Indonesia are also related to customary law, such as in Minang, Bali, Ambon, and Papua . Land can also cause economic, capitalistic, and ideologic problem. Those problems, the conflicts of land dispute, become important parts in the CCL theatre performance "Tanah". Staging "Tanah" is not merely a communication of imagination, but also an alternative where the nation and the world problem is presented as a constructive criticism, understanding, and knowledge. The land conflicts in the dramatic structure of the performance make the performance closed to the spectators problems.

The land problems in Indonesia through the CCL theatre performance "Tanah" show present phenomena packaged in symbols on the theatre stage. Land can be analogized as an agrarian country Indonesia which still imports rice from another country. Trees are cut at random thus cause barren forests causing landslide, which is still a land problem. Land is a place where human beings live and all human problems are on the land they are stepping on. On the land then various symbols are presented as social facts happening in the society.

\subsection{Performing Art Communication of "Tanah" of Theatre CCL Bandung}

Performing art communication of Indonesian contemporary theatre here is shown in performing art communication of "tanah" theatre CCL bandung through communication forms of dramatic, musicalistic, kinesthetic, and visualistic. The principle of those four art communication already mentioned is symbolic communication. The following is the forms of art communication in the performance "Tanah" Theatre CCL Bandung.

\subsubsection{Dramatic Communication}

The dramatic communication in theatre performance "Tanah" is built through the closest affairs of the society as the spectators. There is a freedom to shape dramatic elements as a form of dramatic communication, for example by rajah (a religious Sundanese lyric) or through songs in the performance. Dramatic communication of theatre CCL was built by following the culture tradition of its surroundings. Therefore, it is not bound to the textbook dramatic elements. Dramatic communication becomes living and dead values of this theatre group to instill how the freedom for dramatic expression exists. Dramatic communication is built by theatre CCL by not forgetting the function of art (theatre) among the society by asking; what will you do with theatre performance?

Dramatic communication is related to performance plot and the plot can be built with artistic element through illumination, gesture, music, and the events present in the performance as dramatic symbol. For its love for tradition arts, the dramatic communication of performance "Tanah" theatre CCL is managed through spontaneous and improvised scenes. 


\subsubsection{Musicalistic Communication}

The musicality in performance "Tanah" is considered as a form of musicalistic communication. The closeness with the society of Sundanese tradition makes the communication deriving from the musicality which is the closest to the surroundings. Bringbung music (sort of terbangan or genjring), the music which is usually played in the moment welcoming newborn baby or accompanying the wedding ceremony, is the main music played in this theatre performance.

The practising process of music design suitable for dramatic events in the theatre performance is required to build the musicality communication. However, the presence of music in the performance is not a must, it depends on the need. Musicality can exist without music in the theatre scene as a form of musicalistic communication, for example, through rhythm or tempo of the actors' dialogue, or the tempo of the actors act on the stage. Through musicalistic communication, music can be a symbol in the form of sound, for example, in the performance "Tanah" there is a sound like souldier steps, thus this sound can substitute the presence of soldier troops. The sound of sarong - prok prok prok - which is played is inspired from the movement of washing sarong together, beating the wet sarong against the rock, which symbolize the activity of village people.

\subsubsection{Kinesthetic Communication}

Kinesthetic communication is theatre performing art communication mediated by art movements, such as, the actors movement, dances, property movements, and the movements visualized from the elements on the stage. The elements of kinesthetic communicated needs instilling on the culture life of the surroundings. Kinesthetic elements are related to the culture religiousity of the people surrounding, what is done on the stage becomes kinesthetic religiousity on the real public space.

In the performance "Tanah" the kinesthetic communication is built through the closest tradition to the experience of the performers, for example in scene of playing sarong was inspired from the movement experience of washing sarong and the experience of spectating the art of ronggeng gunung presenting the group of sarong dancers. The scene of playing sarong in "Tanah" is also influenced by mandar fight (fight in sarong), sarong for praying, sarong for art, even sarong for killing. Kinesthetic communication in theatre performance is considered either as symbol or dramatic and musicalistic composition.

\subsubsection{Visualistic Communication}

Visualistic communication in theatre performance is a communication of art elements on a visualized performance, except the auditive ones. The visualization of performance "Tanah" theatre CCL integrates dramatic elements represented by the actors expression, the actors movement, and the property-artistic movement. For instance, the sarong show is visually caught as symbolic visualization, likewise some bamboo properties and other artistic properties, and stage lighting effects becomes very symbolical for performance "Tanah". Visualistic communication becomes very impressive to show the nature surroundings, and the surrounding culture tradition which are contemporarily packaged.

Based on the explanation about art communication in theatre performance, there is a relation between art communication, for example dramatic communication will relate to musicalistic, kinesthetic, and visualistic ones. Meanwhile musicalistic communication has relation with dramatic and kinesthetic ones. Moreover, kinesthetic communication has relation with musicalistic, dramatic, and visualistic ones. While visualistic communication has relation with dramatic and kinesthetic ones. The following is a relation of art communication in theatre performance. 


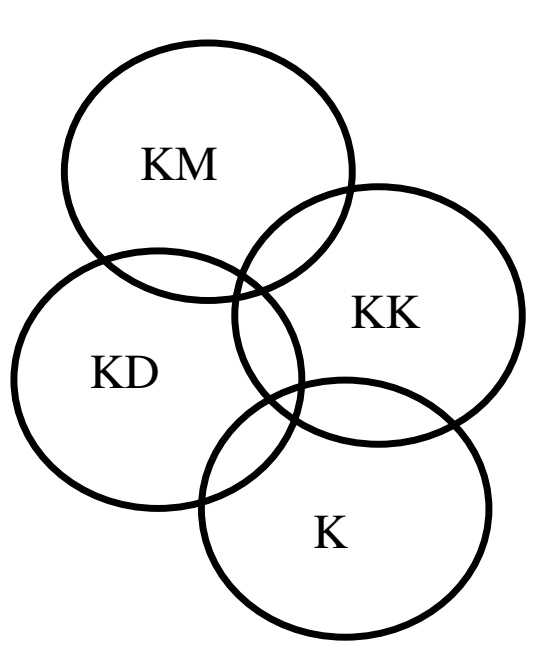

Note:

$\mathbf{K D}=$ Dramatic Communication; existing in $\mathrm{KM}, \mathrm{KK}$, and $\mathrm{KV}$

$\mathbf{K M}=$ Musicalistic Communication; existing in $\mathrm{KD}$ and $\mathrm{KK}$

$\mathbf{K K}=$ Kinesthetic Communication; existing in $\mathrm{KM}, \mathrm{KD}$, and $\mathrm{KV}$

$\mathbf{K V}=$ Visualistic Communication; existing in $\mathrm{KD}$ and $\mathrm{KK}$

Picture 2. The Relation of art communication in theatre performance

\subsection{Sociocultural Construction and the Meaning of Art Communication Message}

The beauty of art is a performance reality constructed by its supporting society, either the performers or the public. In performance "Tanah" of Theatre CCL Bandung, the performance reality is built in group. However, the aesthetic feeling will be sensed subjectively based on their view toward the world. It is here then the role of Berger and Luckmann conception (1990: 210) exists about social construction, in which social reality is social construction created by the individual. This is very much related to Indonesian contemporary theatre performing art communication. Individual becomes a free one to interprete something as beautiful or not. The individual becomes the determiner of art beauty in sociocultural world constructed based on his will. Individual is not a victim of social fact, but as a production machine as well as the creative reproduction one in constructing the beauty on Indonesian contemporary theatre in sociocultural life.

The reality of beauty in performance "Tanah" of theatre CCL Bandung directed by Iman Soleh is created by creative individual through the power of "constructing". To construct as suggested by Barker (2000: 10) is basically a self-reflexive discursive or representative effort to interprete and depict a present world. The performers of art communication of theatre performance do this construction. They create a form of performance which is then communicated to the art public as sociocultural reality. This is possible since their long experience in the performing art realm. Their sense of beauty is sharpened through their art activities. Their experience and their sense guide them to construct the message of "Tanah" in their theatre performance distinctively.

The work or art performers in constructing the meaning of "Tanah" through art communication of contemporary theatre performance can be different. The group of Theatre CCL Bandung has their own characteristic in communicating their art as an effort of sociocultural construction, as shown in the picture below. 


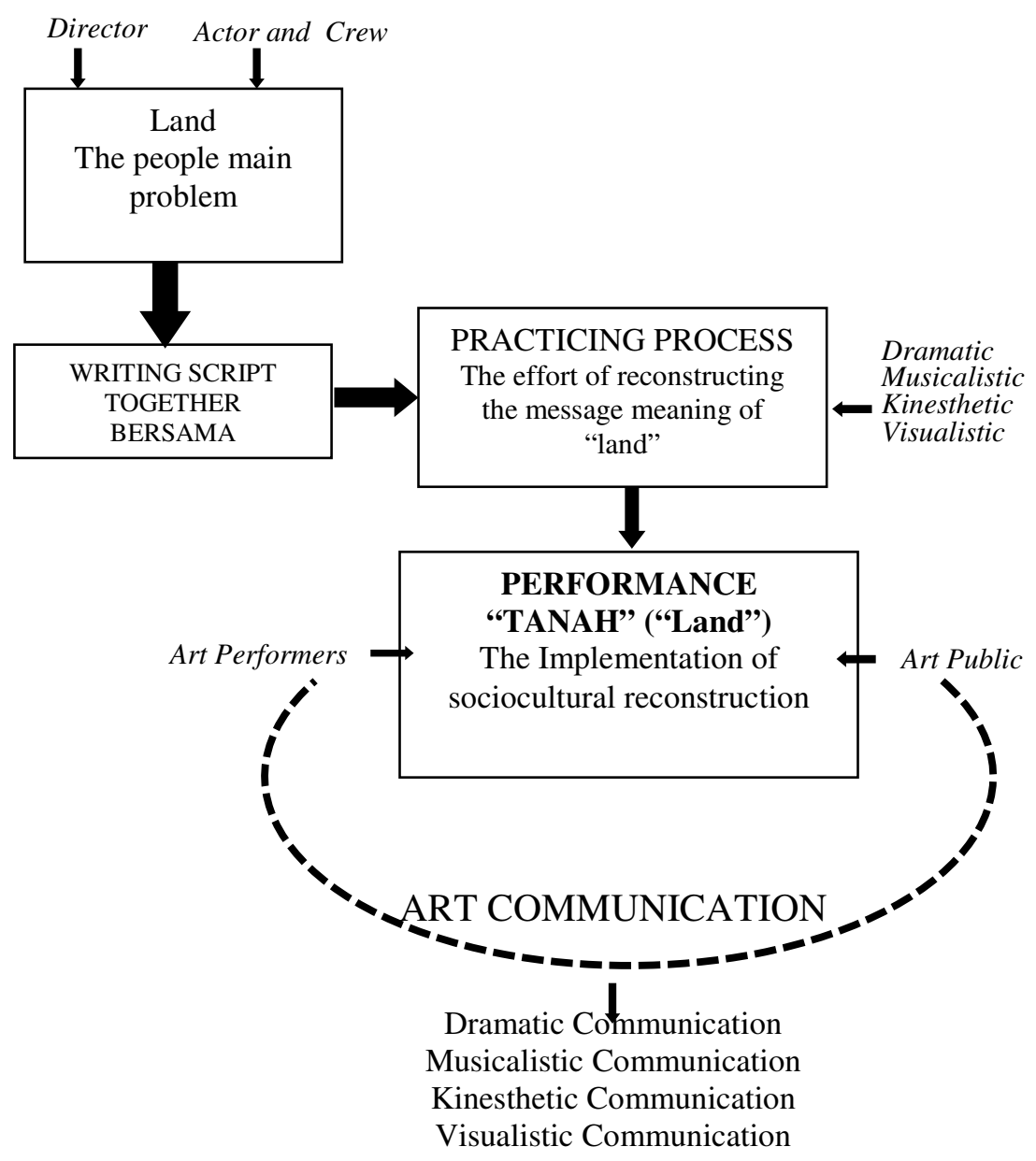

Picture 3. The chart of performing art communication of "Tanah" of Theatre CCL Bandung, Director; Iman Soleh

The way of CCL theatre group in constructing socioculture through performing art communication of "Tanah" is not based on repeating memorized texts but the characterized result of the process as suggested by Koster as composition in performance (Pudentia MPSS, 1998: 38), that is, adapting the words of the story by improvising during the performance. By improvising, the performance "Tanah" performed by theatre CCL Bandung put no distance between the performers and the public. The reality of performance "Tanah" constructed in the event of art communication of theatre performance brings out the meaning of message and the values which disseminate knowledge about "land". The meaning of art communication through performance "Tanah" by presenting the land fights between parties which dominate and which are dominated is not only local or national problems but international one. The war conflicts in Europe and Middle East are not far from the problems of land, surface area, or the expansion of a country. The conflict between Israel and Palestine for instance is caused by fighting for the land. Meanwhile, 500.000 hectare of 1.9 million hectare land in Indonesia is owned by one company. Most of land in Bandung city is dominated by big investors. Land becomes capitalistic economy problems, and it becomes individual too when the village people should sell their field, house, and garden to send their students to school. Instead of enriching people who are going to school, it reduces them to poverty because of loosing their land, field, and garden.

The ilustration above is a picture how theatre performing art elaborates the meaning of performance "Tanah". Theatre should be like that, should function to influence behavior and viewpoint. To have that function, the meaning of the theatre performance should be supported collectively by the performers. This is applied by CCL in performing "Tanah" by preparing the script together involving all performers, the director, actors, musicians, and stage designers. This model to remind the meaning of theatre itself as the creativity built communally. The togetherness is also shown by the art elements composing the theatre performance, such as music, literature/drama, movement/dance, and artistic visualization. 


\subsection{Conclusion}

Cultural and social information in contemporary theatre performance can be a particular knowledge, understanding, and viewpoint in answering sociocultural challenge nowadays. This study offers a new awareness toward the events of contemporary theatre performing art existing in the society, that is, the art life especially theatre performing art is not merely an illustration in life. More than that, performing art is a communication expression in the form of answers, expectations, the picture of the past, the present, and the future life of the society.

There is an inclusive message for theatre through the performance "Tanah" of Theatre CCL, that is, theatre performance should reach narrow streets. The theatre messages should inform the society something that is unreported. The point is, arts especially theatre should not merely build the aesthetic artistic quality but should also consider the essence of life quality in the sociocultural life.

Through this article, the writers would like to thank all CCL theatre performers in Bandung who have willingly spare their time to share about their art activities. Our gratitude also for Research and Public Service Unit of Institute Seni Budaya Indonesia (Indonesian Art and Culture Institute) Bandung which has recommended for this study, and also for Directorate of Research and Public Service of the Ministry of Research, Technology, and Higher Education of Republic of Indonesia which has supplied the grant to conduct this research.

\section{References}

Barker, Chris. 2000, Cultural Studies: Theory and Practice, London: Sage.

Bauman, Richard. 1992. Folklore, Cultural Performances, and Popular Entertainments: A Communications Centered Handbook. New York: Oxford University Press.

Berger, Peter L. dan Thomas Luckmann. 1990. Tafsir Sosial atas Kenyataan: Risalah tentang Sosiologi Pengetahuan, Terjemahan dari The Social Construction of Reality: A Treatise in the Sociological of Knowledge (1966). Jakarta: LP3ES

Burke, Peter. 2003. Sejarah dan Teori-teori Sosial. Jakarta: Yayasan Obor Indonesia (YOI).

Jaeni. 2007. Komunikasi Seni Pertunjukan: Membaca Teater Rakyat Indonesia (Sandiwara Cirebon). Bandung: Etnoteater Publisher.

Jaeni. 2012. Komunikasi Estetik (Menggagas Kajian Seni dari Peristiwa Komunikasi Pertunjukan. Bogor: IPB Press.

Jaeni. 2014. Kajian Seni Pertunjukan dalam Perspektif Komunikasi Seni. Bogor: IPB Press.

Kuswarno, Engkus. 2009, Metode Penelitian Komunikasi Fenomenologi: Konsepsi, Pedoman dan Contoh Penelitiannya, Bandung: Widya Padjadjaran.

Liliweri, Alo. 2003. Makna Budaya Dalam Komunikasi Antarbudaya. Yogyakarta: LKiS.

Pudentia MPSS (ed). 1998. Metodologi Kajian Tradisi Lisan. Jakarta: Yayasan Obor Indonesia dan Yayasan Asosiasi Tradisi Lisan.

Rahmat, Jalaludin. 2002. Psikologi Komunikasi. Bandung: Remaja Rosdakarya. 
The IISTE is a pioneer in the Open-Access hosting service and academic event management. The aim of the firm is Accelerating Global Knowledge Sharing.

More information about the firm can be found on the homepage:

http://www.iiste.org

\section{CALL FOR JOURNAL PAPERS}

There are more than 30 peer-reviewed academic journals hosted under the hosting platform.

Prospective authors of journals can find the submission instruction on the following page: http://www.iiste.org/journals/ All the journals articles are available online to the readers all over the world without financial, legal, or technical barriers other than those inseparable from gaining access to the internet itself. Paper version of the journals is also available upon request of readers and authors.

\section{MORE RESOURCES}

Book publication information: http://www.iiste.org/book/

Academic conference: http://www.iiste.org/conference/upcoming-conferences-call-for-paper/

\section{IISTE Knowledge Sharing Partners}

EBSCO, Index Copernicus, Ulrich's Periodicals Directory, JournalTOCS, PKP Open Archives Harvester, Bielefeld Academic Search Engine, Elektronische Zeitschriftenbibliothek EZB, Open J-Gate, OCLC WorldCat, Universe Digtial Library, NewJour, Google Scholar

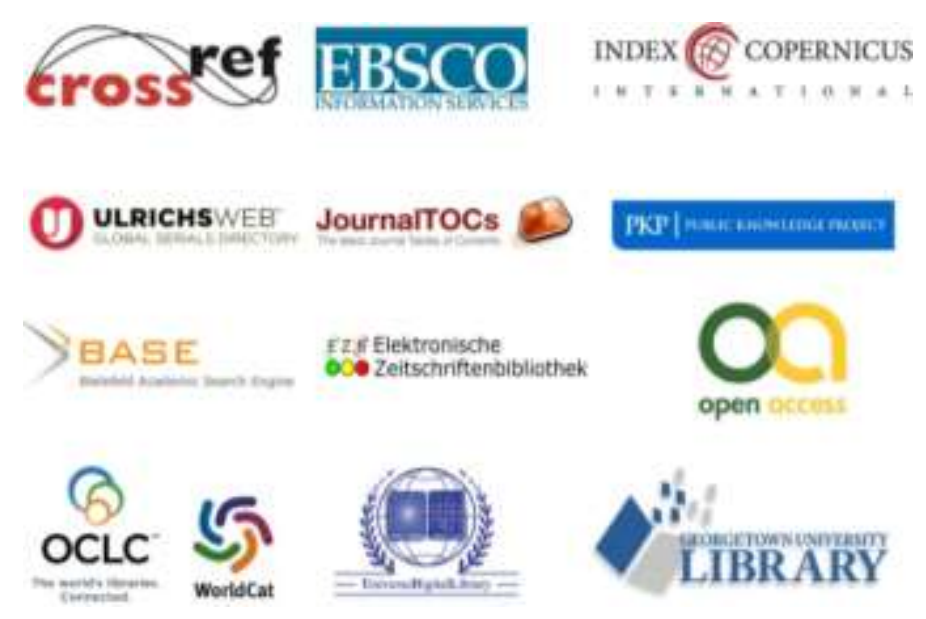

